\title{
DEPHOSPHORIZATION OF OOLITIC GOETHITE IRON ORE BY ROASTING-LEACHING PROCESS*
}

\author{
Wen Xuan ${ }^{1}$ \\ Gilvana Gomes de Souza² \\ Krassimir lonkov ${ }^{3}$ \\ Armando Correa de Araujo 4
}

\begin{abstract}
Oolitic iron ores have significant economical importance because of their extensive resources in the world. However, their utilisation is often quite limited due to the high content of phosphorus inside. The phosphorus is often finely disseminated in the oolite structure and generally not liberated in the form of free particles. The iron ore used in this work is a typical oolitic goethitic iron ore with high phosphorus. The process of phosphorus removal from this ore is difficult because the phosphorus is not present as distinct minerals. As a result, no physical beneficiation process is able to separate the phosphorus from the iron bearing phases. The current concentrate contains low iron grade ( $\mathrm{Fe} \sim 49 \%$ ) and high phosphorus content ( $\mathrm{P} 0.7 \sim 0.8 \%)$. The acid leaching is a potential way to dissolve phosphorus. Previous studies have shown that the thermal treatment makes the phosphorus more accessible for the acids and enables more efficient phosphorus dissolution. Some chemical additives are reported to enhance this phenomenon. A series of tests have been carried out using roasting - grinding - magnetic separation - leaching technologies to remove the phosphorus from this current concentrate. In the first stage, several tests were performed at pilot scale under the same conditions as described in some publications. The achieved results were similar to those from previous tests at laboratory scale. In the second stage, new test conditions were investigated in laboratory scale in order to achieve better result and to reduce the operational cost. Keywords: Oolitic iron ore; Leaching; Roasting; Phosphorus.
\end{abstract}

1 Research Engineer, ArcelorMittal Mining \& Mineral Processing Research Center, Maizières-lèsMetz, France.

2 Student, Universidade Federal de Minas Gerais, Belo Horizonte, Minas Gerais, Brazil.

3 Researcher, Université de Liège, Faculté des Sciences Appliquées, Department ArGenCoGeMMe, Génie Mineral \& Recyclage, Liège, Belgium.

4 CTO Mining Segment, ArcelorMittal Mining \& Mineral Processing Research Center, Voie Romaine, Maizières-lès-Metz, France.

\footnotetext{
* Technical contribution to the 44 Ironmaking and Raw Materials Seminar, $15^{\text {td }}$ Brazilian Symposium on Iron Ore and $2^{\text {nd }}$ Brazilian Symposium on Agglomeration of Iron Ore, September $15^{\text {th }}$ to $18^{\text {th }}$, 2014, Belo Horizonte, MG, Brazil.
} 


\section{INTRODUCTION}

The presence of phosphorus affects directly the quality of steel. The market specification for phosphorus in iron ore is usually below $0.05 \sim 0.1 \%$. Oolitic goethitic iron ore has huge reserve in the world, but it often has high phosphorus content and can therefore not be used directly in steel industry.

As a result, the dephosphorization of this type of iron ore is of significant economical importance. Considerable efforts have been made to develop flowsheets on it. It has been reported that physical separation methods do not remove phosphorus so easily, because the phosphorus is often finely disseminated in the ooids structure and generally not liberated [1].

The iron ore used in this work is a typical oolitic goethite iron ore with high phosphorus. The current concentrate, obtained from gravity-magnetic separation, contains low iron grade ( $\mathrm{Fe} \sim 49 \%$ ) and high phosphorus content (P 0.7 0.8\%). The usage of this ore is quite limited. Roasting and subsequent leaching is a way for upgrading high-P iron ores. This process is more expensive, compared to the conventional upgrading processes. However, in recent times, the increase in world steel production has increased significantly the demand for iron ore, making hydrometallurgical process more viable [2-4].

A recent patent proposed several flowsheets on the dephosphorization of this ore, using roasting with alkali additive, grinding and leaching. By roasting the current concentrate with $5 \mathrm{wt} \%$ anhydrous soda ash, grinding and leaching, a better concentrate with $61.09 \% \mathrm{Fe}, 0.12 \% \mathrm{P}$ and $94.7 \%$ Fe recovery can be expected [5].

This study aims to test the proposed flowsheet and to improve it. In the first stage, several tests were performed at pilot scale under similar conditions as described in the patent. In the second stage, new test conditions were investigated in laboratory scale in order to achieve better result and/or to reduce the operational cost.

\section{MATERIAL AND METHODS}

\subsection{Materials}

The iron ore pre-concentrate was received directly from a concentration plant in north-western Kazakhstan. It was produced from the run-of-mine by crushing, jigging, grinding and magnetic separation.
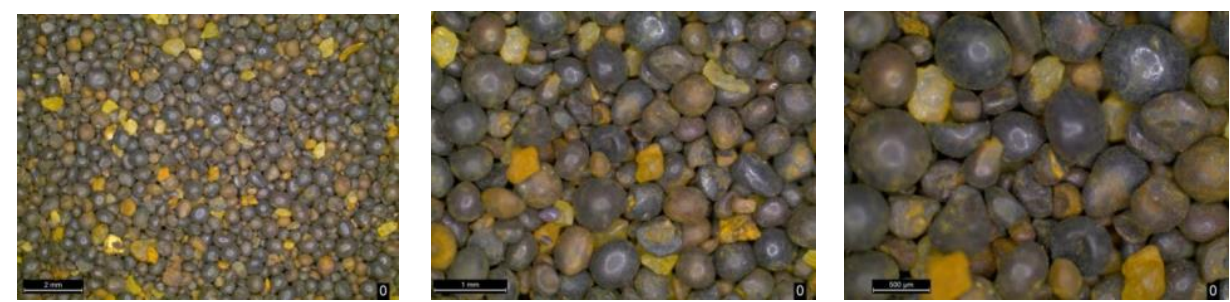

Figure 1: As-received iron ore pre-concentrate picture by optical microscope

The ooids can be seen in Figure 1. Previous studies on this ore have shown that goethite is the main iron bearing mineral; and that silica, aluminium minerals and phosphorus are finely disseminated in the oolitic structure. Quartz has been observed inside and outside the ooids. The chemistry and the size distribution of this iron ore can be seen in Table 1 and Figure 2.

\footnotetext{
* Technical contribution to the $44^{\text {th }}$ Ironmaking and Raw Materials Seminar, $15^{\text {rd }}$ Brazilian Symposium on Iron Ore and $2^{\text {nd }}$ Brazilian Symposium on Agglomeration of Iron Ore, September $15^{\text {th }}$ to $18^{\text {th }}$, 2014, Belo Horizonte, MG, Brazil.
} 
Table 1: Global chemistry of the iron ore concentrate as received

\begin{tabular}{|c|c|c|c|c|}
\hline $\begin{array}{c}\mathrm{Fe} \\
(\%)\end{array}$ & $\begin{array}{c}\mathrm{SiO}_{2} \\
(\%)\end{array}$ & $\begin{array}{c}\mathrm{Ca} \\
\mathrm{O} \\
(\%)\end{array}$ & $\begin{array}{c}\mathrm{Al}_{2} \mathrm{O} \\
3 \%)\end{array}$ & $\begin{array}{c}\mathrm{TiO}_{2} \\
(\%)\end{array}$ \\
\hline $\begin{array}{c}49.8 \\
8\end{array}$ & 10.2 & 0.29 & 4.77 & 0.15 \\
\hline $\begin{array}{c}\mathrm{MgO} \\
(\%)\end{array}$ & $\begin{array}{c}\mathrm{P} \\
(\%)\end{array}$ & $\begin{array}{c}\mathrm{Mn} \\
(\%)\end{array}$ & $\begin{array}{c}\mathrm{N}_{2} \mathrm{O} \\
\mathrm{a} \\
(\%)\end{array}$ & $\begin{array}{c}\mathrm{LOI} \\
(\%)\end{array}$ \\
\hline 0.20 & $\begin{array}{c}0.79 \\
2\end{array}$ & $\begin{array}{c}0.17 \\
6\end{array}$ & $\begin{array}{c}0.07 \\
5\end{array}$ & 11.79 \\
\hline
\end{tabular}

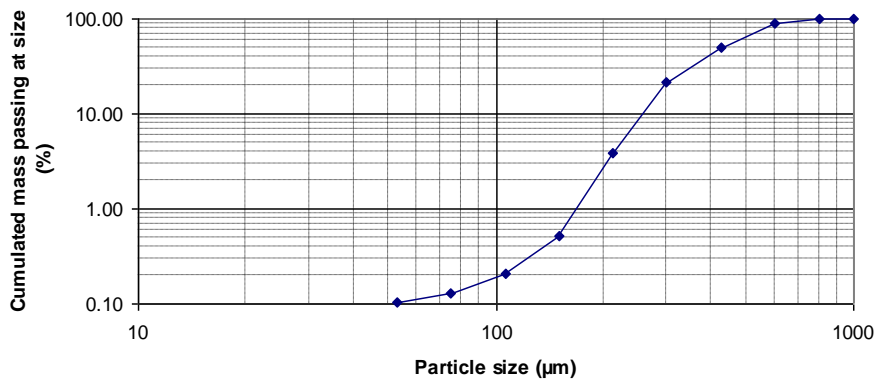

Figure 2: Particle size distribution of the iron ore concentrate as received, by wet sieving

\subsection{Methods}

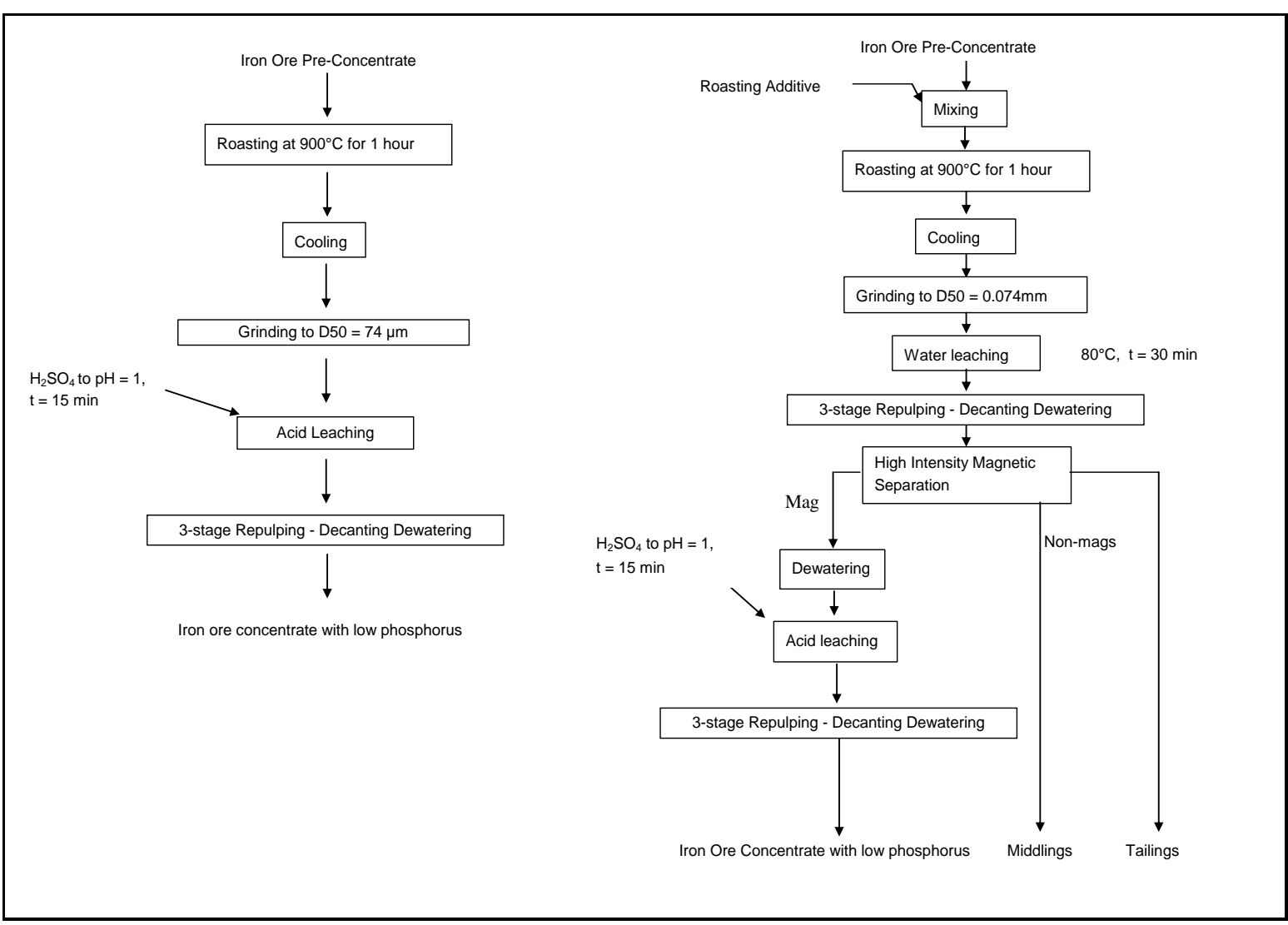

Figure 3: Flowsheet without roasting additive (left), flowsheet with roasting additive (right)

This study consists in two stages. In the first stage, the two flowsheets are tested at pilot scale. The first flowsheet is for comparison; its main process is roasting without

* Technical contribution to the 44 $4^{\text {th }}$ Ironmaking and Raw Materials Seminar, $15^{\text {rd }}$ Brazilian Symposium on Iron Ore and $2^{\text {nd }}$ Brazilian Symposium on Agglomeration of Iron Ore, September $15^{\text {th }}$ to $18^{\text {th }}$, 2014, Belo Horizonte, MG, Brazil. 
additive, grinding, leaching, 3-stage washing and dewatering. The second is the one proposed by the patent, in which the main process is roasting with $5 w t \%$ anhydrous soda ash, grinding, water leaching, 3-stage washing, magnetic separation, acid leaching, 3-stage washing and dewatering. The two flowsheets are described in Figure 3.

In the second stage, laboratory tests were performed to test new roasting additives. Sodium chloride and sodium sulphate were tested because they have been reported in the literature to be efficient in roasting related dephosphorization technologies [6,7]. The best alternative additive was chosen from some preliminary tests with simplified flowsheets, as is described in Figure 4. Afterward this additive was tested in the complete flowsheet.

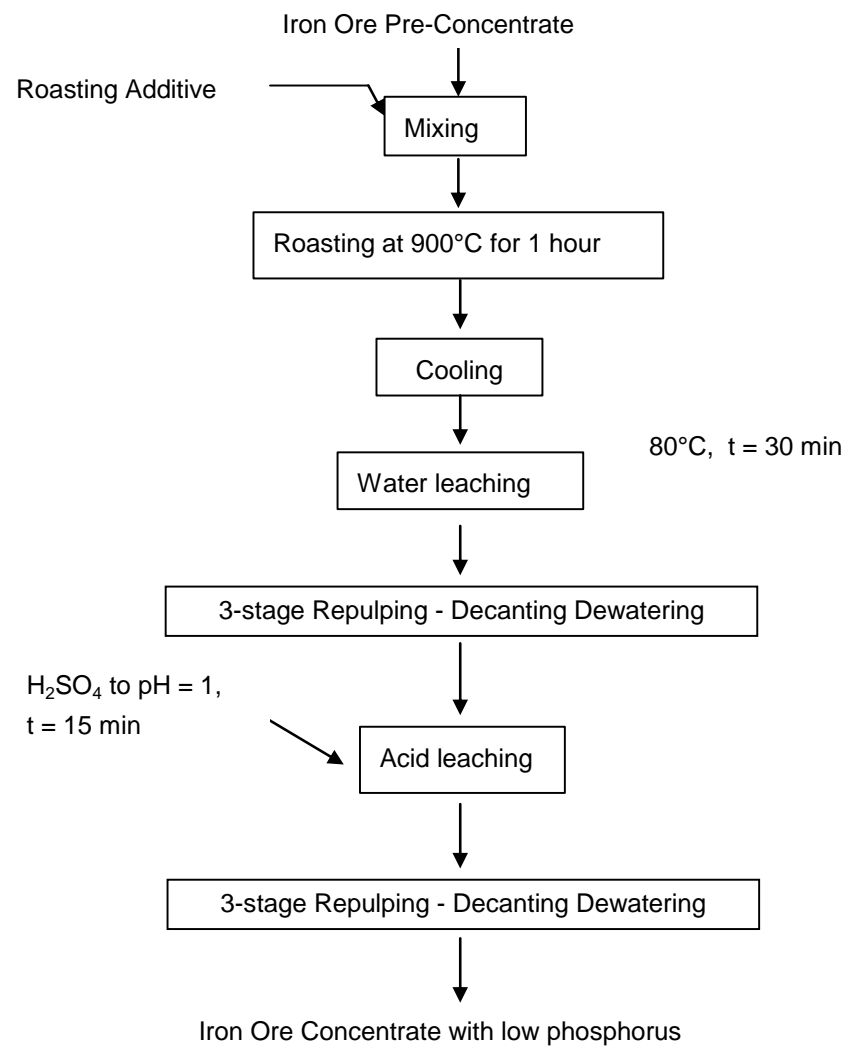

Figure 4: Simplified flowsheet for the choice of alternative roasting additive

\subsection{Equipments for Pilot Test}

\subsubsection{Roasting}

At pilot scale, the roasting test was performed with a semi-industrial rotary kiln in Institut für Strömungstechnik und Thermodynamik in Otto Von Guerike Universität (Magdeburg, Germany). The roasting test was done in a semi-industrial rotary kiln with a total length of $L=5 \mathrm{~m}$ and an inner diameter of $\mathrm{D}=0.4 \mathrm{~m}$. The kiln is direct fired with a natural gas burner and has a refractory lining with a thickness of swall $=150 \mathrm{~mm}$. The operational parameters of the rotary kiln are described in Table 2.

* Technical contribution to the $44^{\text {th }}$ Ironmaking and Raw Materials Seminar, $15^{\text {rd }}$ Brazilian Symposium on Iron Ore and $2^{\text {nd }}$ Brazilian Symposium on Agglomeration of Iron Ore, September $15^{\text {th }}$ to $18^{\text {th }}$, 2014, Belo Horizonte, MG, Brazil. 
Table 2: Operational parameters of the rotary kiln

\begin{tabular}{|l|l|l|}
\hline Parameter & Iron ore without additive & Iron ore with $5 \% \mathrm{Na}_{2} \mathrm{CO}_{3}$ \\
\hline Solid Mass Flow & $40 \mathrm{~kg} / \mathrm{h}$ & $40 \mathrm{~kg} / \mathrm{h}$ \\
\hline Rotational Speed & $0.6 \mathrm{rpm}$ & $0.6 \mathrm{rpm}$ \\
\hline Kiln inclination & $1.0^{\circ}$ & $1.0^{\circ}$ \\
\hline Burner Power & $110 \mathrm{~kW}$ & $100 \mathrm{~kW}$ \\
\hline Overall mean residence time & $190 \mathrm{~min}$ & $190 \mathrm{~min}$ \\
\hline Residence time over $900^{\circ} \mathrm{C}$ & $70 \mathrm{~min}$ & $44 \mathrm{~min}$ \\
\hline
\end{tabular}

Representative roasted product was taken for the following steps: grinding, acid leaching, and in the case of the second pilot test water leaching and magnetic separation.

\subsubsection{Grinding}

The grinding was performed in a "Palla" vibrating rod mill from MBE Coal \& Mineral Technology (Cologne, Germany).

\subsubsection{Leaching}

The leaching was performed in a mini-plant in Otto-Von-Guericke Universität (Magdeburg, Germany) that is equipped with a thermally controlled batch stirred tank, gravimetric automatic dosing of acid / base for $\mathrm{pH}$ control and online and in-situ process control of $\mathrm{pH}$ and temperature.

\subsubsection{Magnetic separation}

The magnetic separation was performed using a Jones ${ }^{\circledR}$ (WHIMS) high intensity wet magnetic separator at MBE Coal \& Mineral Technology (Cologne, Germany), employing the following parameters:

Table 3: Parameters for the WHIMS magnetic separation

\begin{tabular}{|l|l|}
\hline Solid content in the pulp & $400 \mathrm{~g} / \mathrm{L}$ \\
\hline Magnetic Field & 1.4 Tesla \\
\hline Gap & $0.7 \mathrm{~mm}$ \\
\hline
\end{tabular}

In the second stage, a third flowsheet was tested in laboratory scale, using new roasting additives, namely sodium chloride and sodium sulphate.

\section{RESULTS AND DISCUSSION}

\subsection{Pilot test without Roasting Additive}

As can be seen in Figure 5, roasting without additive resulted in limited phosphorus removal. The phosphorus content remained $0.635 \%$ in the final concentrate. The leaching process probably requires more time because of the low speed in diffusion. It seems that the reaction only took place on the surface.

\footnotetext{
* Technical contribution to the $44^{\text {th }}$ Ironmaking and Raw Materials Seminar, $15^{\text {rd }}$ Brazilian Symposium on Iron Ore and $2^{\text {nd }}$ Brazilian Symposium on Agglomeration of Iron Ore, September $15^{\text {th }}$ to $18^{\text {th }}$, 2014, Belo Horizonte, MG, Brazil.
} 

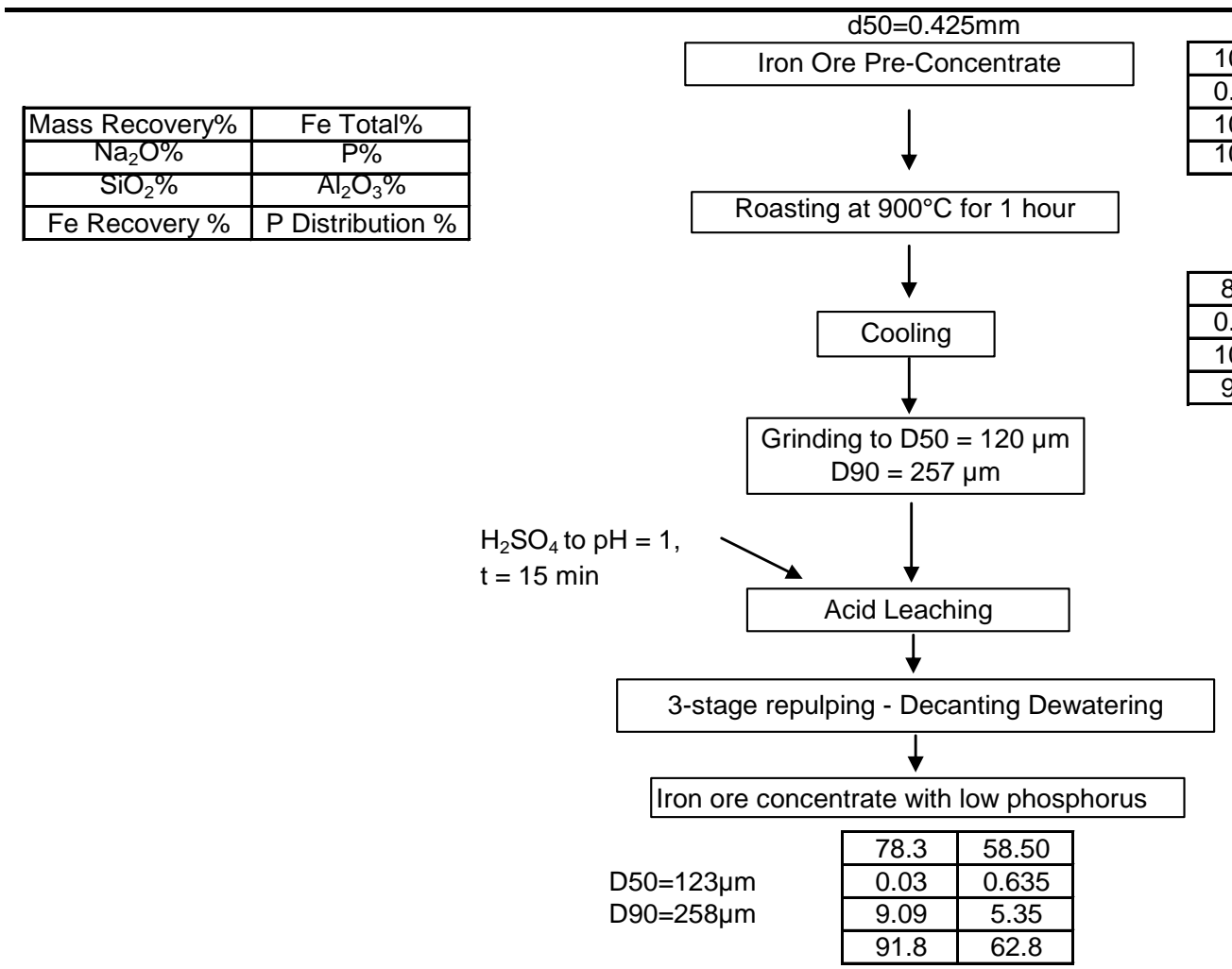

\begin{tabular}{|c|c|}
\hline 100.0 & 49.88 \\
\hline 0.075 & 0.792 \\
\hline 10.20 & 4.77 \\
\hline 100.0 & 100.0 \\
\hline
\end{tabular}

\begin{tabular}{|c|c|}
\hline 86.1 & 56.38 \\
\hline 0.050 & 0.896 \\
\hline 10.36 & 5.48 \\
\hline 97.4 & 97.4 \\
\hline
\end{tabular}

Figure 5: Result of the pilot test without roasting additive

The consumption of sulphuric acid to maintain $\mathrm{pH}$ at 1 for 15 minutes is $13.7 \mathrm{~kg}$ $\mathrm{H}_{2} \mathrm{SO}_{4} / \mathrm{t}$ leaching feed. This confirmed the low reactivity. Besides, it is impossible to remove silica without magnetic separation.

\subsection{Pilot test with 5\% Sodium Carbonate as Roasting Additive}

As can be seen in Figure 6, that roasting with soda ash is very helpful to the dephosphorization by acid leaching. This test achieved a satisfying result: $\mathrm{P} 0.121 \%$, Fe $63.6 \%$ at $70.2 \%$ iron recovery.

Magnetic separation is efficient to remove a part of the liberated silica and alumina contaminants. Another part, that is not liberated, can be partially removed by acid leaching. The leaching kinetics with the contaminant elements such as P, Si and Al are much faster than that with $\mathrm{Fe}$. The ratio $\mathrm{Si} / \mathrm{Fe}$ in the leachate is about 80 times higher than it is in the feed; and the ratio $\mathrm{Al} / \mathrm{Fe}$ about 200 times higher. The final concentrate contains $\mathrm{SiO}_{2} 4.23 \%$ and $\mathrm{Al}_{2} \mathrm{O}_{3} 3.43 \%$. The leachate after acid leaching contains high concentration of the contaminants. The analysis of the leachate after acid leaching can be seen in Table 4.

* Technical contribution to the $44^{\text {th }}$ Ironmaking and Raw Materials Seminar, $15^{\text {rd }}$ Brazilian Symposium on Iron Ore and $2^{\text {nd }}$ Brazilian Symposium on Agglomeration of Iron Ore, September $15^{\text {th }}$ to $18^{\text {th }}$, 2014, Belo Horizonte, MG, Brazil. 


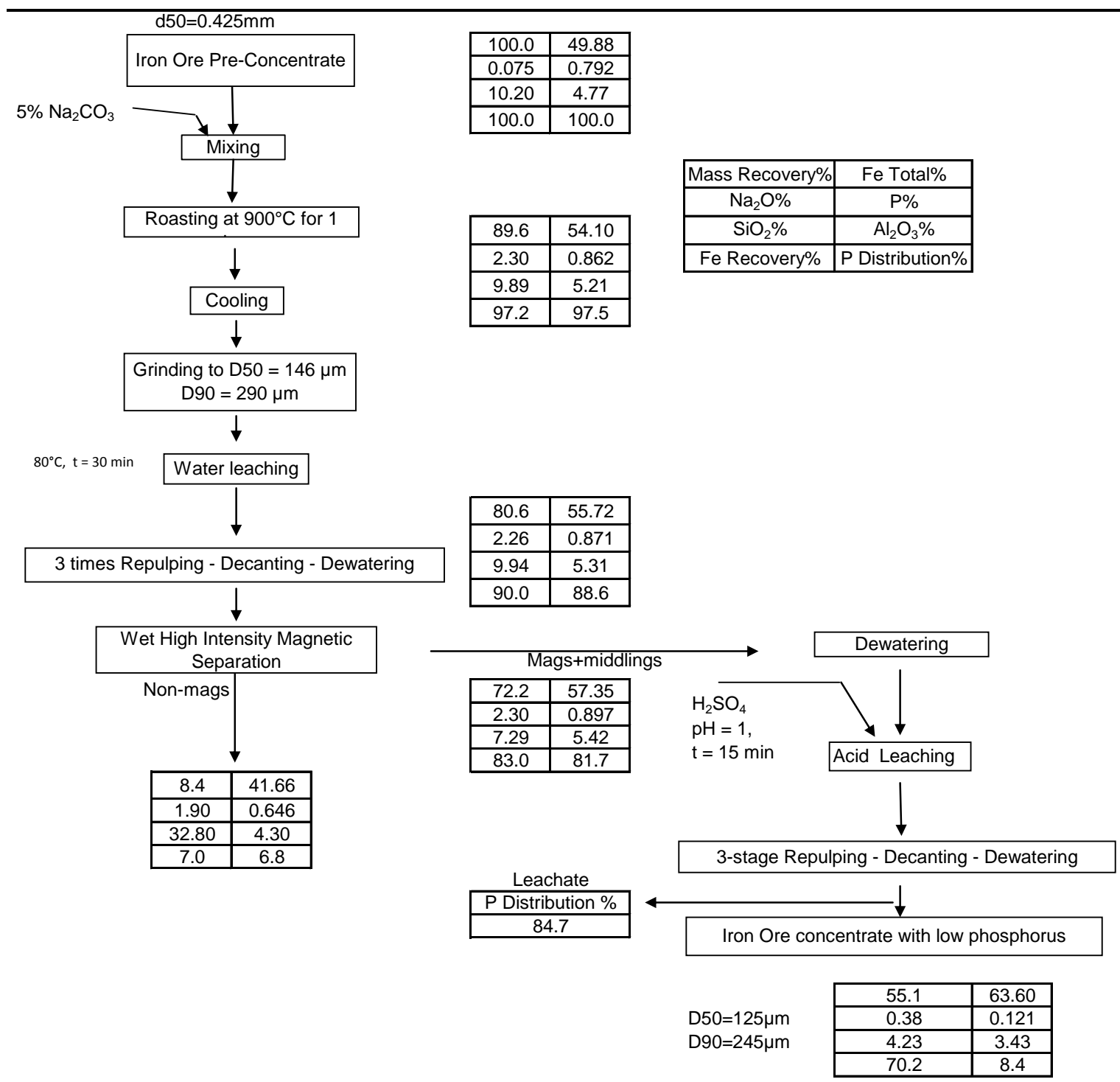

Figure 6: Result of the pilot test with $5 w t \%$ soda ash as roasting additive

Table 4: Water analysis of the liquot after acid leaching

\begin{tabular}{|c|c|c|c|}
\hline $\mathrm{P}(\mathrm{g} / \mathrm{L})$ & $\mathrm{Si}(\mathrm{g} / \mathrm{L})$ & $\mathrm{Al}(\mathrm{g} / \mathrm{L})$ & $\mathrm{Fe}(\mathrm{g} / \mathrm{L})$ \\
\hline 3.87 & 4.54 & 4.87 & 0.588 \\
\hline
\end{tabular}

The acid consumption was $148 \mathrm{~kg} \mathrm{H}_{2} \mathrm{SO}_{4} / \mathrm{t}$ leaching feed.

The sodium introduced by $\mathrm{Na}_{2} \mathrm{CO}_{3}$ was partially removed by magnetic separation, and mostly removed by the acid leaching.

\subsection{Laboratory tests with Alternative Roasting Additive}

Laboratory tests were performed according to the simplified flowsheet described in Figure 4, using either sodium chloride or sodium sulphate as roasting additive at $5.6 \mathrm{wt} \%$. Grinding and magnetic separation were not used as the main criterion is the chemical reaction to remove phosphorus. The main results can be seen in Table 5.

\footnotetext{
* Technical contribution to the $44^{\text {th }}$ Ironmaking and Raw Materials Seminar, $15^{\text {rd }}$ Brazilian Symposium on Iron Ore and $2^{\text {nd }}$ Brazilian Symposium on Agglomeration of Iron Ore, September $15^{\text {th }}$ to $18^{\text {th }}$, 2014, Belo Horizonte, MG, Brazil.
} 
Table 5: Main results from the tests to choose an alternative roasting additive

\begin{tabular}{|c|c|c|c|c|c|c|c|c|}
\hline Additive & $\begin{array}{c}\text { Mass } \\
\text { Recovery\% }\end{array}$ & $\mathrm{Fe} \%$ & $\mathrm{P} \%$ & $\mathrm{SiO}_{2} \%$ & $\mathrm{Al}_{2} \mathrm{O}_{3} \%$ & $\begin{array}{c}\mathrm{Fe} \\
\text { Recovery\% }\end{array}$ & $\begin{array}{c}\mathrm{P} \\
\text { Distribution\% } \%\end{array}$ & $\begin{array}{c}\text { Acid } \\
\text { Consumption } \\
\mathrm{H}_{2} \mathrm{SO}_{4} \mathrm{~kg} / \mathrm{t} \\
\text { leaching feed }\end{array}$ \\
\hline $5.6 \mathrm{wt} \% \mathrm{NaCl}$ & 76.3 & 58.6 & 0.192 & 10.6 & 3.7 & 89.6 & 18.5 & 78 \\
\hline $5.6 \mathrm{wt} \% \mathrm{Na}_{2} \mathrm{SO}_{4}$ & 80.8 & 54.8 & 0.705 & 11.1 & 4.8 & 88.6 & 72.0 & 10 \\
\hline
\end{tabular}

Sodium chloride was thus chosen, as it is much more efficient in phosphorus removal.

\subsection{Laboratory test with New Roasting Additive in the Complete Flowsheet}

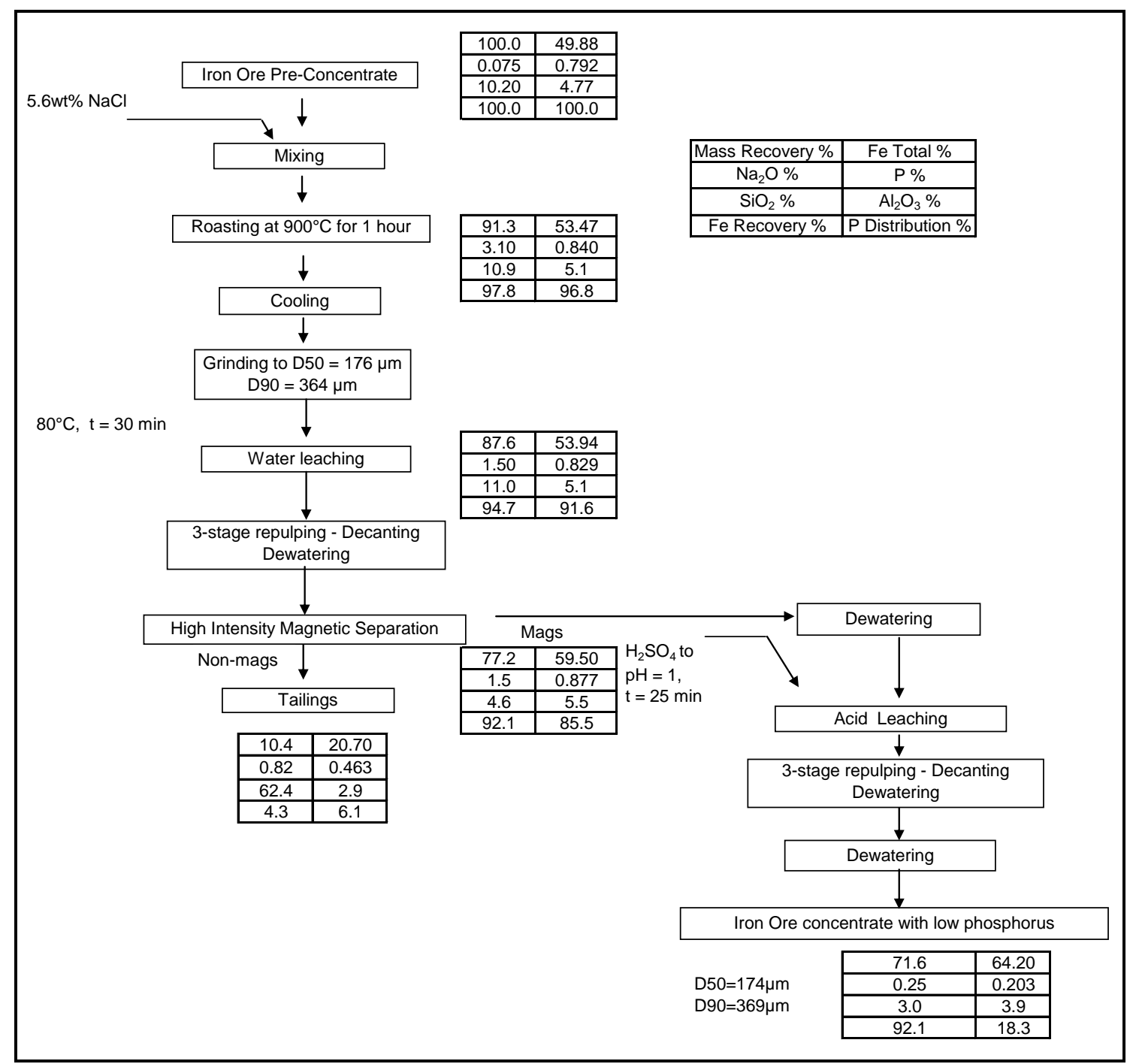

Figure 7: Laboratory test with $\mathrm{NaCl}$ as alternative roasting additive in the complete flowsheet

The results of this test are depicted in Figure 7. This test proves that sodium chloride is also a good roasting additive for dephosphorization. It can help to produce a concentrate at $64.2 \% \mathrm{Fe}, 0.203 \% \mathrm{P}$ at $92.1 \% \mathrm{Fe}$ recovery.

The sodium introduced by $\mathrm{NaCl}$ was partially removed by magnetic separation, and mostly removed by the acid leaching.

The acid consumption was $70 \mathrm{~kg} \mathrm{H}_{2} \mathrm{SO}_{4} / \mathrm{t}$ leaching feed.

* Technical contribution to the $44^{\text {th }}$ Ironmaking and Raw Materials Seminar, $15^{\text {rd }}$ Brazilian Symposium on Iron Ore and $2^{\text {nd }}$ Brazilian Symposium on Agglomeration of Iron Ore, September $15^{\text {th }}$ to $18^{\text {th }}$, 2014, Belo Horizonte, MG, Brazil. 


\section{CONCLUSION}

The tests proved that it is possible to remove most of the phosphorus from this oolitic goethite iron ore by roasting - leaching technologies. It was demonstrated at pilot scale that the flowsheet that includes roasting with soda ash is efficient in dephosphorization. Laboratory tests proved that sodium chloride is a good alternative roasting additive in this flowsheet.

Roasting without additive or roasting with sodium sulphate followed by acid leaching did not remove phosphorus in an efficient way.

The mechanism of roasting with sodium-based additive is still not well known. It seems that soda ash or sodium chloride plays an important role in roasting. It likely transforms the phosphorus into a new phase that can react with sulphuric acid quite fast at room temperature.

\section{Acknowledgments}

The authors wish to thank JProf. Dr.-Ing. Fabian Herz and Prof. Dr.-Ing. Eckehard Specht, both from Otto-Von-Guericke Universität Magdeburg, for their contribution during the execution of the pilot roasting tests. The professional and kind help of Dr. Albena Ognyanova and Dr. Karl-Heinz Becker from MBE Coal \& Mineral Technology on grinding and magnetic separation is greatly appreciated. Dr.-Ing. Andreas Schlinkert and Prof. Dr. Jürgen Tomas from Otto-Von-Guericke Universität Magdeburg are gratefully acknowledged for their assistance in leaching. Special thanks go to Rafael Vaz from Universidade Federal de Minas Gerais for his assistance in the laboratory testwork and data analysis. The discussion with Prof. Stoyan Gaydardzhiev from the University of Liège is very valuable and important to the accomplishment of the entire work.

\section{REFERENCES}

1 Kokal HR: "The Origin of Phosphorus in Ironmaking Raw Materialsand Methods of Removal - A Review", 63RD Annual Meeting of the Minnesota Sectionaime, 51st Annual Mining Symposium, 18 January 1990 (1990-01-18), pages 225-257, XP009168184, Duluth, Minnesota

2 Kokal HR, Singh MP, Naydyonov V. Removal of phosphorus from Lisakovsky iron ore by roast - leach process. Hydrometallurgy - proceedings of the 5th international symposium, Vol, 2 Vancouver, B. C. Canada. The minerals, metals and materials, society (T M S ) Warrandale PA 15086, USA (2003), 1517 - 1530.

3 lonkov K, Gaydardzhiev S, Araujo AC, Kokal H, Pirson A. Dephosphorisation of Limonitic Iron Concentrate by Roasting, Acid Leaching and Magnetic Separation, Iron Ore 2011, Perth, Australia, pp $445-452$.

4 lonkov K, Gaydardzhiev S, Araujo AC, Bastin D, Lacoste M. Amenability for processing of oolitic iron ore concentrate for phosphorus removal Minerals Engineering, 2013; 4647: 119-127.

5 Gaydardzhiev S, lonkov K, Bastin D, Araujo AC, Pirson A, Kokal H. Method for of processing an iron ore containing phosphorus Patent Pub. No. WO/2014/009769.

6 Feld IL, Franklin TW, Lampkin WM. Process for removing phosphorus from iron ores 1966, US Patent, No 3402041.

7 Li G, Zhang S, Rao M, Zhang Y, Jiang T. Effects of sodium salts on reduction roasting and Fe-P separation of high-phosphorus oolitic hematite ore. International Journal of Mineral Processing, 2013; 124: 26-34.

\footnotetext{
* Technical contribution to the 44 Ironmaking and Raw Materials Seminar, $15^{\text {rd }}$ Brazilian Symposium on Iron Ore and $2^{\text {nd }}$ Brazilian Symposium on Agglomeration of Iron Ore, September $15^{\text {th }}$ to $18^{\text {th }}$, 2014, Belo Horizonte, MG, Brazil.
} 